\title{
SAN ADRIÁN DE MONEIXAS. EVOLUCIÓN DE LA IGLESIA Y ESTUDIO DE SU SINGULAR PINTURA MURAL
}

\author{
M. ${ }^{a}$ ESTHER DEL CASTILLO FONDEVILA
}

\begin{abstract}
Resumen
La iglesia de San Adrián de Moneixas (Lalín-Pontevedra) de fábrica románica en origen con fecha próxima a 1170 , conserva de aquel momento poco más que el arco de acceso a la capilla mayor y las columnas sobre las que descansa, rematadas por capiteles decorados.

Muy reformada en el segundo y tercer cuarto del siglo XVIII, la dotan de una sacristía, una ventana en el ábside, dos nuevas capillas, el retablo mayor, otros tres retablos y la espadaña, todo ello de factura barroca

En 1960 una gran transformación la desfigura completamente, ya que construyen una Capilla-Santuario a modo de segunda nave, dedicada a la Tercera Orden Carmelitana.

En el interior del muro de la Epístola del ábside, apareció con motivo de unas obras, una original pintura mural, inédita hasta ahora. Creemos puede datarse a fines del XV o muy principios del XVI. Representa la Flagelación, con la particularidad de seguir un modelo poco habitual en España, tomado del Speculum Humanae Salvationis, en el que Cristo aparece atado a una palmera mientras dos sayones lo azotan.
\end{abstract}

\section{Palabras clave}

Iglesia, retablo, pintura mural, Flagelación.

\begin{abstract}
The church of Saint Adrian of Moneixas (Lalín - Pontevedra) was originally a Romanic factory dated about 1170 . From that time, it only keeps the arch leading to the High Chapel and the columns on which the arch rests. The columns end in decorated capitals. Between the second and third quarter of the eighteenth century the church suffered several reparations, and it was provided with a sacristy, a window in the apse, two new chapels, the main altarpiece and other three retables and the bell gable -all of them in baroque style.

In 1960 the church is completely transformed - a Sanctuary-Chapel was built as if it was a second nave, and it was dedicated to the Third Carmelite Order.

Inside the wall of the apse epistle and because of some works, there appeared an original mural painting, unknown up to now. We think that it can be dated as belonging to the late fifteenth century or very early in the sixteenth. It represents the Flagellation of Christ, with the particularity that it follows an unusual pattern in Spain taken from the Speculum Humanae Salvationis, in which Christ appears tied to a palm tree while two men belonging to the brotherhood of the "executioners" "sayones" are whipping him.
\end{abstract}

\section{Keywords}

Church, altarpiece, mural painting, Flagellation of Christ. 


\section{ESTUDIO EVOLUTIVO DE LA IGLESIA}

La iglesia de San Adrián de Moneixas se encuentra en la parroquia del mismo nombre, dentro del término municipal de Lalín en la provincia de Pontevedra, diócesis de Lugo.

Elías Valiña ${ }^{1}$ indica que según la tradición en el emplazamiento de la feligresía hubo un convento de monjas, el cual sería el origen del topónimo, considerando este mismo autor que la denominación de otro lugar próximo de la misma parroquia, Moneixiñas, deriva del sitio que ocupaban las aspirantes o novicias.

Sean o no ciertas estas hipótesis de su vinculación monástica, no nos atrevemos a poner en entredicho tales aportaciones.

Isidro Bango aconseja incluir la fábrica del templo románico en fecha inmediatamente anterior a 1170, a juzgar por los escasos restos que se conservan. Para ello, se basa sobre todo en la forma del arco triunfal de acceso a la capilla mayor y en la decoración de las columnas sobre las que descansa.

Reinaba entonces en Galicia D. Fernando II de León, siendo obispo de Lugo D. Juan $^{2}$. De ese momento lo único que ha llegado a nuestros días es la cabecera con ábside rectangular. Esta forma absidal es característica de las tierras de Deza y Trasdeza pudiendo verse en ellas otros muchos ejemplos.

La parte superior del ábside ha perdido el alero decorado tal vez con canecillos, si bien podemos apreciar en el muro sur una columna central entrega, de la que perviven la basa y algunos tambores del fuste, faltándole el capitel. En el testero saetera con arco de medio punto al exterior.

Interior con arco triunfal semicircular doblado, que apoya en sendas columnas rematadas por capiteles decorados a base de carnosas hojas y volutas entre las que asoman en uno la cabeza de un animal y en el otro una cabeza humana. Bajo los capiteles se disponen ábacos achaflanados y fustes de tambores desiguales que parten de basas áticas ornadas con motivos de garras y cabecitas en la parte de la escocia. Dentro de la capilla mayor, en paralelo al descrito, un segundo arco de similares características, con los apoyos semejantes, carente de las cabezas en los capiteles.

Cubre el espacio absidal una bóveda de cañón enlucida, que se separa del muro a través de una imposta que alcanzaba el muro de la nave.

Desconocemos en qué momento los capiteles y ábacos del arco triunfal se desmochan.

\footnotetext{
${ }^{1}$ Elías Valiña, "Catálogo de los archivos parroquiales de Lugo...", p. 403

${ }^{2}$ García Conde, A. y López Valcarcel, A., "Episcopologio lucense”, p. 187
} 
Los muros del ábside aparecen horadados en la actualidad, el de la izquierda por la puerta de la sacristía mandada hacer, por el Arcediano de Deza D. Juan Roque Arias y Somoza a decir del auto de la visita del 13 de julio de $1730^{3}$ : “...y respecto no tiene sachristia acosta de dhos alcances la mande hazer en la parte mas comoda q le pareciere y surta dha. Iglesia de lo mas necessario a su culto y dezencia..." En las cuentas de 1732 figura en el descargo la cantidad de "mill docientas y ochenta y quatro r y quatro mr pa la fabrica nueva deuna sacristia de Boveda que se hizo en dha Igla la q fue ajustada en en millquatrocientos y ochenta y un reales de vellon."

$\mathrm{Y}$ el de la derecha por una ventana que tal vez se abra en $1747^{5}$ "...treinta rr de blanquear la Ig ${ }^{l a}$. y abrirle una fenestra y hacer unos asientos $p^{a}$ los sacerdotes oficiar".

En la pared de la Epístola, en ese mismo ámbito, hubo dos nichos que en el auto de 1737 el obispo ordenó tapiar6 "Que los huecos queay al lado del Altar mor , seygualen de canteria..." "Que dos Nichos queay en la pared al lado dela Epist ${ }^{\text {la. Sin }}$

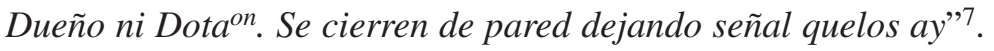

Los muros del ábside y su bóveda enlucidos mostraban pintura mural, de la cual todavía pueden apreciarse ligeros restos tras las columnas del lateral izquierdo, en el testero, que hoy aparecen ocultos por el retablo y en el lateral derecho, en donde se conserva una original escena que ha sido recuperada en la última restauración y nos ha dado pie a escribir estas líneas.

La iglesia, hoy muy modificada, contaba con dos cubiertos a los lados, que fueron suprimidos en 1737 por orden del obispo D. Cayetano Gil Taboada ${ }^{8}$ Que los dos cubiertos que tienen los colaterales Que uno de ellos amenaza ruina se saquen y sus materiales se aprovechen en utilidad de la Igla...”

Además le añadieron las dos capillas laterales, dedicadas a Sta. Lucía y a Ntra. Sra. de la Angustia. Estas capillas, en origen de factura barroca, sustituyen a los altares colaterales mencionados en el Libro de fábrica en una anotación de 1678, que refiere un repinte de imágenes de estos altares 9 “ “... quinientos $R$ que costo repintar el retablo e ymagines delos altares colaterales y altar mayor..."Precisamente de aquel retablo mayor sabemos que fue trasladado 10 "En el lugar de Velelle de Catasós ay una capilla de la gloriosa Virgen y martir Sta Marina...que rredificó parte

\footnotetext{
${ }^{3}$ Libro de fábrica, f. $71 \mathrm{vl}$

${ }^{4}$ Libro de fábrica, f. 73,74vl-v

${ }^{5}$ Libro de fábrica, f. $99 \mathrm{v}$

${ }^{6}$ Libro de fábrica, f. $84 \mathrm{v}-\mathrm{vl}$

${ }^{7}$ Libro de fábrica, f. 86vl

${ }^{8}$ Libro de fábrica, f. $84 \mathrm{v}$

${ }^{9}$ Libro de fábrica,f. $9 \mathrm{vl}$

${ }^{10}$ Libro no. I (1581-1820), f. 432
} 
della D. Igazio Nuñez cura que fue en $\mathrm{dh}^{a} \mathrm{Fr}^{a}$ y posteriormente se le puso el rretablo que actualmente existe que hera el unico que avia en la Igla de Moneixas...". Pero hoy este retablo no existe, en su lugar hay uno actual de madera barnizada carente de todo interés, a excepción de dos de sus imágenes, un Santiago y una Virgen, reaprovechadas de alguno antiguo. Cabe preguntarse ¿de cuándo eran esas imágenes? Desconocemos la respuesta, si bien los últimos folios del hasta aquí tantas veces mencionado Libro de fábrica, llevan por título "Razon puntual de lo travajado enla Igla de Moneixas eneltpo que fuy su indigo Capp ${ }^{n}$ ", fueron escritos por D. Pablo Verea y Aguiar, y en ellos resume lo más relevante de la fábrica del templo en los años de su capellanía. Allí dice ${ }^{11}$ "ÂA 1738 Hizose el Presviterio dela Cap ${ }^{a}$ mayor, sacaronse los colaterales de piedra, cerraronse unos nichos y se hizon otros precisos rreparos", indicando incluso el folio en el que se trata el referido epígrafe a modo de índice. Así en la data y rebaja al depositario de aquel año, precisamente se rebajan 12 “...ciento diez y nueve $R^{\text {es }}$ y medio quetubo de coste el hazer el Presviterio dela capillama ${ }^{\text {or }}$ : quitar los colaterales antiguos, hazerlos altares de nuevo..."

En la visita de 1740 D. Juan Roque Gill Arias y Somoza, Arcediano de Deza, reconoció el Libro de la fábrica, con las cuentas pertenecientes a los frutos de 1739, en cuyo descargo figura el importe del retablo de la capilla mayor y los elementos de su composición, sus imágenes y el artista que lo ejecutó13. "Iten Mill y quatrocientos rr quetubo de coste el Retablo dela capillamar consu custodia Camarín y efigies de Nuestra Sra del Rosario, San Adrian y Apostolos San Pedro, y San Pablo q ejecuto Antonio Bernardo de Cande, enqueha de entrar la hechura del marco parael frontal sin envargo deque dho Maestro repite mas cant ${ }^{d}$." Un poco más adelante, en el alcance contra la fábrica dice ${ }^{14}$ "...admas deveinte y nueve $r r$ y $\mathrm{m}^{\circ}$, quellebaron dejornal losoficiales que hizieron el altar paradho rretablo enq entra lamadera, ..."

En ese mismo folio, después de las firmas del auto correspondiente de la visita, hay una anotación en la que se lee ${ }^{15}$ “ En Veinte demr ${ }^{z o}$ desietz $^{o s}$ y quarenta y uno Reci ${ }^{i}$ deD ${ }^{n}$ Pablo de Verea Cura deSan Adrian de Moneixas quatrocientos y veinte rr enq fue conzertada la Pintura dela Custodia y Camarín y efiguie de $N^{R A} S^{r a}$ del Rosario dedhadedha Igla de Moneixas de cuia cant ledoi recibo $p^{a}$ surresguardo". El texto continúa por detrás finalizando con la firma de Juan de Saabedra ${ }^{16}$. “...y ochorr para los oxos de cristal dela efiguie de $N^{\text {ra }}$ Sra $^{\text {del Rosario." }}$

\footnotetext{
${ }^{11}$ Libro de fábrica,f. 200

${ }^{12}$ Libro de fábrica, f. 86v-vl

${ }^{13}$ Libro de fábrica, f. $89 \mathrm{vl}$

${ }^{14}$ Libro de fábrica, f. $90 \mathrm{v}$

${ }^{15}$ Libro de fábrica, f. $90 \mathrm{v}$

${ }^{16}$ Libro de fábrica, f. 90vl
} 


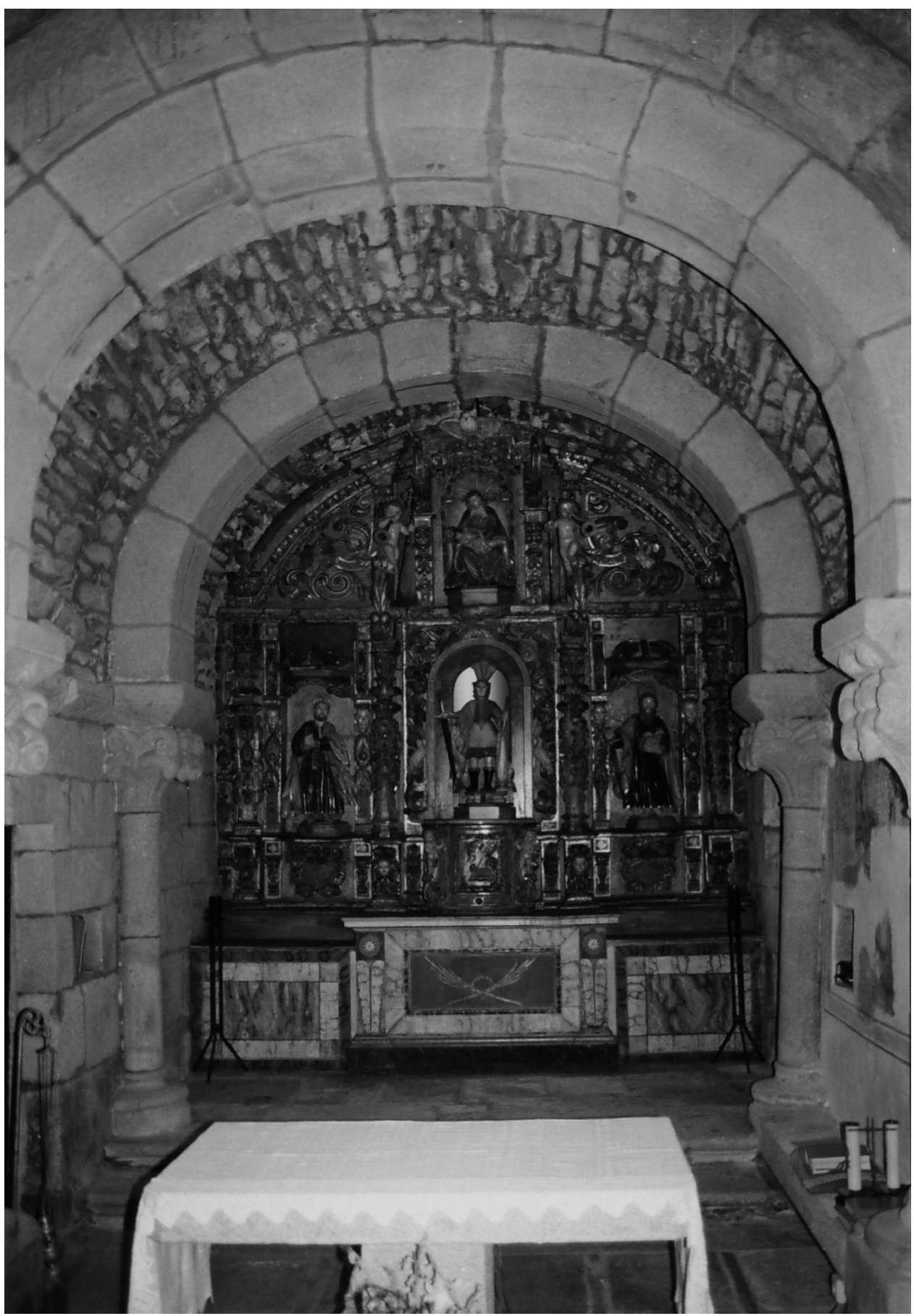


El 22 de agosto de 1741 es el propio obispo D. Caietano Gill Taboada, quien visita la fábrica de esta iglesia y en nota apunta ${ }^{17}$ “....y quatrocientos y veinte rr que entrego a Juan de Savedra por lapintura delaefiguie de Nra S ${ }^{r a}$ del Rosario, Custodia y Camarín, segn consta derrecivo quesealla enestelibro (el que copiamos líneas atrás) ,... yrevajados loscienrr q por r ${ }^{o n}$ deornatos pagaron los herederos de $D^{n}$. Ignacio Nuñez...”. Esta última cantidad rebajada se refiere a que cuando compra los ojos de cristal de la Virgen, estos herederos, que lo son de su antecesor, le pagan una deuda contraída por su familiar al mayordomo y D. Pablo de lo suyo devuelve el dinero, que sabía se debía a la fábrica, ordenando su Ilustrísima que le sea reintegrado.

$\mathrm{Al}$ acudir al final del Libro de fábrica, en donde se relacionan a modo de resumen las principales obras realizadas, nos encontramos con que aquí también hay anotaciones referentes al retablo de la capilla mayor. Así la primera, que tropezamos dice ${ }^{18}$ : "Â de 40:Hizose el retablo de la Cap ${ }^{a} a^{\text {or }}$ (pues elantiguo nohera otromas, deel que tiene la Capp a de Velelle) pintose el Camarín, y serrpararon otrascosas qe anotan al fol.090."

Todos estos datos no hacen otra cosa que confirmar y completar lo que ya sabíamos por la información que proporcionan las cartelas dispuestas en su predela en las que podemos leer, en la diestra "HIZOSE ESTE RETABLO EL ANO DE 1739 SIENDO CURA D PABLO VEREA" y en la siniestra "Y AGUIAR POR TITULO DE JOSE MONTENEGRO”.

Por la descripción de los elementos, nos podemos hacer una idea más o menos aproximada de lo que pudo ser el conjunto antes de su mutilación. Sin duda algo mucho más espectacular que lo que hoy vemos, pues aunque las alusiones al camarín no corresponden, ni nunca correspondieron con la existencia de un autentico camarín, que según palabras de Martín González puede definirse como una modificación del retablo en la que ${ }^{19}$ " La hornacina principal se perfora, de suerte que hay detrás una cámara, a la que accede el pueblo, para adorar de cerca la imagen. Con frecuencia este camarín recibe luz por una ventana situada detrás (el transparente)". En la iglesia de Moneixas no hay espacio suficiente para hacer la cámara que permitiese el acceso a la gente para acercarse a la imagen, pero sí debió existir la ya mencionada estructura turriforme o de templete en la que iría colocada la Virgen iluminada desde atrás, buscando un efectismo lumínico, muy del gusto barroco, que le proporcionaría la ventana o más bien alguna lámpara puesta en ese

\footnotetext{
${ }^{17}$ Libro de fábrica, f. $91 \mathrm{v}$

${ }^{18}$ Libro de fábrica, f. 200

19 J.J. Martín González, “Escultura barroca en España.1600-1770”, p. 27
} 
lugar porque, como ya anotamos en la parte correspondiente a las obras de la iglesia en general, dicha ventanilla, una saetera por donde poca luz podía pasar, había ordenado el obispo tapiarla en 1737 de cal y canto.

Hoy encontramos una obra que podemos encuadrar dentro de la tipología retablística de conjunto con diversidad de soportes.

Así podemos ver como entre sus calles alternan los estípites con una especie de columnas abalaustradas, recurriéndose en ambos casos a decorar casi la totalidad de la superficie del elemento portante con motivos diversos, en su mayoría de carácter vegetal.

Estructurado en tres calles, con banco, un cuerpo y ático amplio; se centraba con un baldaquino que albergaba a la Virgen del Rosario, este elemento ya no existe, como también se ha perdido la imagen mariana.

Dedicado a San Adrián, titular de la parroquia, éste estaba situado ocupando la hornacina superior, en donde en la actualidad se ha colocado a la Virgen de la Angustia, que pertenecía a otro retablo desaparecido. La disposición del resto de las imágenes ocupa sus posiciones primitivas, así San Pedro va colocado en el cuerpo principal en la calle de la derecha, mientras que a San Pablo se reserva el mismo emplazamiento pero en la calle de la izquierda.

El santo patrono muestra atuendo militar con coraza de placas y manto sobre el hombro, con casco de plumas. Si bien la faldilla rayada bajo la cual asoman una especie de pololos de tela fruncida no parecen corresponder al uniforme usado por el ejército romano, aunque este incluía pantalón corto. Calza botas, en vez de las típicas sandalias de Roma. Lleva espada en su mano derecha, mientras en la zurda sostiene un puñal en lugar de la llave que debería portar según la iconografía. En vez del característico yunque, aquí vemos una columna a la que une su brazo izquierdo por medio de una soga anudada.

San Pedro, va vestido de apóstol con toga antigua y manto, las manos entrecruzadas delante en actitud de oración, lo que corroboran sus ojos mirando al cielo; calvo, con barba corta, cana y descalzo con dos llaves colgando de sus muñecas y nimbo de santidad.

Las dos llaves son la fórmula más generalizada de encontrar tal elemento. Simbolizan las 20 "llaves del cielo y de la tierra", "el poder de atar y desatar, de absolver y de excomulgar, que Cristo concediera al Príncipe de los apóstoles (Tibi dabo claves regni coelorum). Suelen ser una de oro y otra de plata y las ponen juntas en señal de que el poder de abrir y de cerrar es uno, considerándose a su portador como portero del cielo.

${ }^{20}$ Réau, Louis "Iconografía de los santos", p. 51 
En el San Pedro de Moneixas ahora pueden verse dos llaves doradas aunque estas son modernas y tal vez las originales fueran de diferente color. Su aspecto de hombre maduro, incluso algo mayor, concuerda con lo que los textos dicen de él y es la forma más habitual de su imaginería.

San Pablo viste túnica con manto sobre los hombros al uso del siglo I, va descalzo y porta espada en su mano derecha con la hoja apuntando hacia abajo y libro abierto en la izquierda, hacia el cual dirige su mirada. Muestra espesa cabellera, así como larga y poblada barba, con el pelo oscuro. Sobre el cráneo el nimbo que indica su santidad.

Dos angelitos trompeteros con sendas cruces de Santiago guardan los lados de la hornacina del ático que remata en la paloma que simboliza al Espíritu Santo.

En el banco, bajo las hornacinas laterales, dos cartelas en las que podemos leer el texto recogido párrafos atrás.

Los pedestales que soportan las columnas centrales van adornados con querubines, mientras flanqueando el sagrario, decorado con el Agnus Dei, disponen dos angelitos portando un racimo de uvas y una espiga de trigo, ambos símbolos eucarísticos propios de semejante emplazamiento.

Los mismos símbolos eucarísticos, esta vez siendo picoteados por dos palomas, se repiten formando parte del adorno de las tablas laterales de la hornacina central, la cual ha experimentado una gran transformación, ya que en vez de esta, originalmente habría allí un baldaquino con tal vez cuatro columnas que soportaban un dosel, bajo el que se cobijaba la imagen principal, semejante a una custodia turriforme procesional y sin duda de estructura abierta. Se han encontrado los anclajes de dos columnas, pero esto es insuficiente para poder recrear su aspecto. También se muestra alterada la posición del sagrario que avanzaría notablemente, lo cual es lógico, porque tal como está ahora, oculta sus laterales y estos fueron labrados con demasiado cuidado para no ser vistos. Además dicho avance permitía ofrecer una base estable al baldaquino, que a bien seguro producía un golpe de efecto en el retablo, ganando mucho en teatralidad, característica esencial del mundo barroco.

El retablo no presenta un programa iconográfico coherente por lo que pensamos que el autor del encargo D. Pedro Joseph de Montenegro Mosqueras y Oxea, clérigo, dueño de la Casa de D. Freán y miembro de una poderosa familia, y el rector de la parroquia entonces, D. Pablo Verea y Aguiar, no lo dispusieron, sino que se limitaron a ordenar la colocación de unas imágenes de su especial devoción, aunque la razón de su elección la desconocemos.

Por plantear una hipótesis que explique en cierto modo el motivo por el que fueron escogidas las imágenes citadas en el Libro de Fábrica se nos ocurre la siguiente proposición: 
El retablo se dedicaría al patrono de la parroquia San Adrián, dispuesto en el ático de la arquitectura.

Ocupando el centro de la misma, destacada y alojada en un baldaquino, la Virgen en su advocación del Rosario, elegida no sabemos por qué. Flanquean a la Madre de Dios, los príncipes de la iglesia, los santos apóstoles San Pedro y San Pablo; este último figura, tal vez como santo patrón de D. Pablo Verea y San Pedro como santo principal de la Iglesia oficial y primero de los sacerdotes, de ahí que lo eligiera, dada su condición eclesial, D. José de Montenegro.

Corona el conjunto la paloma, símbolo del Espíritu Santo, desde los primeros tiempos del cristianismo que lo toma de los fragmentos evangélicos que narran el Bautismo de Cristo: Mateo, 3,16. “Bautizado Jesús, salió al punto del agua, y he aquí que se le abrieron los cielos y vio al Espíritu de Dios, en figura de paloma que descendía y venía sobre Él”.

Entre los elementos arquitectónicos distinguimos sirviéndoles de complementos decorativos pequeños angelitos algunos portando emblemas eucarísticos, que se concentran en torno al sagrario, sobre cuya puerta está el Cordero Místico y en los laterales los jarrones de flores, aludiendo a la pasión, como sumo sacrificio que se ofrece a Dios para alcanzar la redención.

El Cordero Místico es un símbolo basado en que para los judíos ese animal era el elegido para el sacrificio a Dios, la Biblia lo recoge como primera víctima grata al Creador cuando Abel lo ofrece a Dios. Génesis, 4,3-5: "Pasado algún tiempo, presentó Caín a Yahvé una ofrenda de los frutos de la tierra. Y también Abel ofreció de los primogénitos de su rebaño, y de la grasa de los mismos. Yahvé miró a Abel y su ofrenda; pero no miró a Caín y su ofrenda, por lo cual se irritó Caín en gran manera, y decayó su semblante.”

Insisten los textos sagrados en otros pasajes, en la condición del cordero como sacrificio ideal. Este animal pasa al cristianismo como emblema de Jesucristo, ya que el profeta Isaías, en el texto de su escrito bíblico, describe al Mesías que había de venir como el cordero sacrificado por los pecados de los hombres" . "Eramos todos como ovejas errantes, seguimos cada cual nuestro propio camino; y Yahvé cargó sobre él la inquinidad de todos nosotros. Fue maltratado, y se humilló sin decir palabra, como cordero que es llevado al matadero; como oveja que calla ante sus esquiladores, así él no abre la boca”. Y como tal vuelve a hacerlo el evangelista San Juan en su Evangelio y en el Apocalipsis"22: "Al día siguiente vio Jesús que venía hacia él, y dijo: "He aquí el cordero de Dios que lleva el pecado del

\footnotetext{
${ }^{21}$ Isaías, cp. 53,6-7

${ }^{22}$ San Juan "Evangelio", cap. 1, 29
} 
mundo"23. "Y vi que en medio delante del trono y de los cuatro vivientes y de los ancianos estaba de pie un Cordero...". De nuevo va a ser identificado el cordero por la Iglesia desde sus comienzos, como lazo de unión entre el cordero pascual del Antiguo Testamento y el Cordero Pascual del Nuevo Testamento, que será el Cuerpo y la Sangre de Cristo contenidos en la Eucaristía.

Los jarrones de flores, precisamente estos jarrones con flores fueron muy populares en las manifestaciones artísticas, sobre todo desde el siglo XVI, adoptando la presencia de dichas flores una intención simbólica.

La simbólica de la botánica procede de la Antigüedad Clásica, manteniéndose a lo largo de la Edad Media, pues como otros atributos característicos de los dioses paganos fueron asimilados por el cristianismo adquiriendo una simbología propia de aquella religión.

La literatura piadosa medieval creó alegorías en las que valiéndose de los símbolos vegetales se expresaban preceptos morales basados en la Historia Sagrada.

En el Renacimiento se produce el gran auge de los emblemas y las empresas, derivados de la tradición jeroglífica, del simbolismo, de la mitología y de la literatura clásica; fruto de ello surgen obras basadas en estos principios que alcanzan un éxito espectacular, como los Emblemas de Alciato, que tendrán también una enorme repercusión en el Barroco.

Este lenguaje, que ahora nos puede parecer tan complejo, se extendió de tal modo, que no sólo los humanistas y eruditos lo dominaban, por el contrario hasta las clases populares se habían familiarizado con él y les ayudaba a comprender y memorizar el mensaje que se les quería transmitir a través de tales elementos.

Entre las especies florales de este jarrón distinguimos tres tipos diferentes, las rosas, los claveles y una tercera variedad que no acertamos a catalogar, aunque tal vez se trate de otra clase de rosa, ya que esta flor es un símbolo de la Pasión de Cristo.

Las rosas rojas se asocian a la sangre y ya desde el siglo IV se encuentran textos piadosos que asemejan a la rosa con la sangre de Cristo. Tal vez aquí se representen ejemplares de "rosa Gallica" o "rosa Castellana" y "rosa Rubra", ambas rojas aunque esta última se nos antoja muy dudosa.

Los claveles fueron muy representados desde el siglo XV en el arte religioso, relacionándolos con Jesucristo. Por su denominación latina "Dianthus", se establece tal relación, ya que significa "flor de Dios". Se le atribuyeron propiedades medicinales cuya simbología condujo a relacionarlos con la salvación cristiana.

\footnotetext{
${ }^{23}$ San Juan “Apocalipsis”, cap. 5, 6.
} 
Todavía resta otro punto confuso; éste atañe a ciertos elementos tales como las cabezas de las polseras del ático, que tal vez pudieron ser reaprovechados de un retablo anterior, del que hay constancia en la documentación conservada.

Volviendo al devenir histórico de la iglesia, concretamente a la visita de 1741 el obispo, ordena ${ }^{24}$ "Y que se haga un Altar colat Advocazon de Sta. Lucia y encargamos a este cura que se haga cosa que sea dezente y la efigie la costee la Cofradia y Hermanos de ella". Hemos de esperar hasta 1742 para toparnos con dos partidas destinadas al pago de estos colaterales, mencionando aquí el texto quien fue su escultor" ${ }^{25}$. "Y porque este Cura hizo los dos colaterales desta Igla. Quetubieron de coste ocho cientos rreales quellebo Juan Sarrapio escultor por su fabrica..." 26 "...Iten quince rr del oficial que hizo los dos altares colaterales”; recoge también el índice el particular ${ }^{27}$ : "Â 42 Sefabricaron los Dos Colaterales queactualm ${ }^{\text {te }}$ existen porqueantes no los havía...” .

$\mathrm{Al}$ año siguiente más partidas, destinadas al adorno de tales piezas 28 "Iten setentay seis rr quetubieron de coste los frontales delos dos colaterales".

El mayor se pintó y doró en 1747; nos imaginamos que serían las partes que no se habían acometido con anterioridad, es decir la casi totalidad del mismo a excepción del camarín e imagen principal ${ }^{29}$. "Y porquese pinto y doró el retablo principal destta Igla enpro de Mill y seiscientos rr, porultimo ajuste" 30 . "ÂA de 47: Se Doró y pintó el retablo dela Cpp a mayor yrrepararon otras cosas precisas y expresadas en la Visita dese año".

Y en 1748 pintan los colaterales ${ }^{31}$ : "En Dez vre de 1748, sepintaron los dos colaterales dela Igla de Moneijas enpr ${ }^{o}$ de unmil y ses ${ }^{a}$ rr ultimo precio en quepude ajustar, Para lo qual heservido alas gloriosas Santa Lucia y Sta. Maria Madalena..." "delos mill y sesenta que costo la pintura de dhos colaterales"32. "Â 48 Sepintaron y Doraron los Dos Colaterales De las Capillas N. S. Dela Angustia y S. Lucia”.

A los cinco años en el 53, es necesario intervenir en los muros de la nave y aprovechan para rehacer la espadaña ${ }^{33}$. "Yporque eneste pres ${ }^{\text {te }}$ año, serredificaron las paredes de los costados de esta Igla queseallaban amenazando ruina; y se hizo la

\footnotetext{
${ }^{24}$ Libro de fábrica, f. $86 \mathrm{v}-\mathrm{vl}$

${ }^{25}$ Libro de fábrica, f. $91 \mathrm{vl}$

${ }^{26}$ Libro de fábrica, f. $92 \mathrm{vl}$

${ }^{27}$ Libro de fábrica, f. $93 \mathrm{v}$

${ }^{28}$ Libro de fábrica, f. 200

${ }^{29}$ Libro de fábrica, f. 99vl

${ }^{30}$ Libro de fábrica, f. 200

${ }^{31}$ Libro de fábrica, f. $96 \mathrm{v}$

32 Libro de fábrica, f. 103v

${ }^{33}$ Libro de fábrica, f. 201
} 
espadaña de ella..."34 "Â: 53 serredificaron las paredes De los costados dela Nave Dela Igla que amenazaban ruina; y conlos despoxos, sefabrico la Espadaña actual;a vista deqe la antigua herapequeña..." Una nota del libro de la visita de 1757 informa del coste de unas pieles para el frontal del altar mayor ${ }^{35}$ : “...y och ${ }^{a} y$ ocho rr dequatro pieles para frontal del altar maior".

1761 aparece como data de los frontales de los colaterales ${ }^{36}$ : "Cientoy sesenta rr quetubieron decoste la echura y madera delos Dos frontales delos altares colaterales"; mas ¿ no se habían costeado estos en 1743 ?

En la misma fecha, el escultor de Louredo hará el retablo e imagen de la Virgen de la Angustia para la sacristía ${ }^{37}$. "Trescientos rr que se entregaron al escultor de Louredo porla echura del retablillo y efigie de $\mathrm{Nr}^{a} \mathrm{~S}^{\mathrm{ra}}$ de la Angustia colocada en la sacristia..." "Â. 61 Se hizon los frontales delos altares delas Dos Capillas, el retablill dela sacristia enq esta la efigie de S. $M^{a}$ Magdalena; la medalla de N. S. de la Angustia que se coloco enla Cap ${ }^{a}$ deel evangelio $p^{a}$ quien ultimam ${ }^{\text {se te }}$ sefabrica, como se dirá enotro lugar."

Al siguiente año nueva partida destinada al mencionado escultor por su trabajo ${ }^{39}$ : "Ciento y veinte y cinco rr que llebo el escultor de Louredo por la echura deel colateralcillo de la sacristia, andas, y Dos frontales de los altares colectorales...". Y otra para el pintor Andrés Oxea que remata esos elementos ${ }^{40}$. "Ducientos y cinq${ }^{t a} \mathrm{rr}^{e s}$ quellebo Andres Oxea pintor porpintar la lamina de $N^{r a}$ Señ ${ }^{a}$ de la Angustia, andas; y frontales de los colaterales..." 41 "Â: 62 Pintáronse la efigie de N. S. dela Angustia, andas; frontales de los colaterales...” El ejemplar de Moneixas, pese a ser denominado en los Libros de fábrica como Nuestra Señora de la Angustia, es una Piedad al estilo de las de los últimos siglos medievales con Cristo sentado sobre las rodillas de María y recostado en horizontal, semi de espaldas a ella, mostrando la herida del costado y con los pies en el aire.

El grupo adopta una base ancha de esquema triangular, dotándose a la Madre de mayor canon que al Hijo, cuando al ser este un adulto y lógicamente por su condición masculina, debería alcanzar mayores proporciones. Esta reducción del canon de Jesús alude al sentimiento maternal que lleva a las madres a ver siempre como

\footnotetext{
${ }^{34}$ Libro de fábrica, f. $116 \mathrm{v}$

${ }^{35}$ Libro de fábrica, f. $122 \mathrm{vl}$

${ }^{36}$ Libro de fábrica, f. 201

${ }^{37}$ Libro de fábrica, f. $129 \mathrm{v}$

${ }^{38}$ Libro de fábrica, f. $129 \mathrm{v}$

${ }^{39}$ Libro de fábrica, f. 201

${ }^{40}$ Libro de fábrica, f. $131 \mathrm{v}$

${ }^{41}$ Libro de fábrica, f. $131 \mathrm{vl}$
} 
niños a sus hijos, así como también a que como tal niño que es, ella lo acuna entre sus brazos mientras duerme, en un intento de dulcificar la tragedia que se basa en una concepción de los místicos franciscanos. Dentro de esta misma concepción hallamos el rostro de la Virgen, en el que vemos a una mujer joven en exceso, teniendo en cuenta la edad con la que se representa a su Hijo.

La Señora abraza el cuerpo de Jesús con dulzura y la expresión de su cara muestra una tristeza contenida sin rasgos de desesperación.

Sobre el pecho femenino no aparecen los cuchillos de los dolores, atributos iconográficos de las Angustias.

Hecho este inciso en la evolución del templo, reanudamos su seguimiento, así de 1768 hallamos otra nueva nota por la que se da cuenta del coste de la tarima del altar mayor. Esta, en la actualidad no existe ${ }^{42}$. "Veinte y quatro $r$ de la tarima deel altar ma ${ }^{\text {or }}$ y conpos ${ }^{\text {on }}$ deel presbiterio."

Iniciados los setenta surgen nuevas referencias de obras, de 1771 es la construcción de la capilla de la Angustia33: "... para ayuda dela fábrica de una Capilla q"

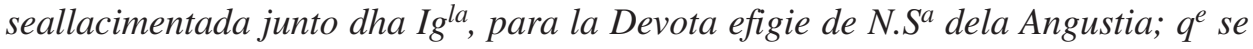
venera con incomodidad ensusacristia.". Del 72 hay ${ }^{44}$ : "Unmill ciento ynobenta y siete $r r$, que sirvieron y sirven para ayuda dela obra dela capilla; ensanche, y elevacion dela sacristia enq $q^{\text {actualm }}{ }^{\text {te }}$ seestá trabajando". "En este año pres ${ }^{\text {te }}$ de mill sietez $^{o s}$ setenta y dos se edifico la Capilla de Nuestra Señora de la Angustia y serredificó la sacristia porallarse (aunque sufabrica moderna) ynutil, estrcha y sofoca$d a$, demanera queq ${ }^{\text {to }}$ serrecoxia en ella se destruia conla abundanzia dehumedad desuprecisasitu ${ }^{\text {on }}$ para cuios efectos se hizo precisa la elevacion de la Capilla ma ${ }^{\text {or }}$ desde su antiguaBoveda arriba enla conformid enqueactualm $^{\text {te }}$ sealla y con la posible Decencia $=$ Habieron de coste las tres rreferidas piezas Mill y nubez ${ }^{o s} \mathrm{rr}$ antemas quemenos y fuera mayor suimporte anoser lamucha piedra de canteria quetenia dha sacristia y parede que se rronpio de la Igla para fabricar el arco dela expresada Capilla"45. "Â.72 Sefabrico la Capilla de N.S. dela Angustia, ensanchandose la sacristia y Capilla ma ${ }^{o r}$, para que servio lapiedra dela sacristia antigua, queseallaba de bobeda; pero pequeña sin luz y muy sofocada y humeda."

Metidos en obras, éstas prosiguen durante un año más, para acometer los reparos de la nave y la construcción de la capilla de Sta. Lucía ${ }^{46}$. “...teja para lanabe

\footnotetext{
42 Libro de fábrica, f. $143 \mathrm{v}$

43 Libro de fábrica, f. 201

${ }^{44}$ Libro de fábrica, f. $142 \mathrm{vl}$

45 Libro de fábrica, f. 147, 148

${ }^{46}$ Libro de fábrica, f. 202
} 
dela Igla medie estabaporlaparte de abajo destruida toda la antigua"47. "Yporque

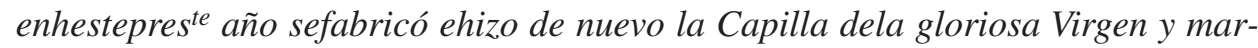
tir, la Señora Santa Lucía, uetubo de coste de cien ducados ynclusamadera, fierro y piedra; enla conformidad quesealla permanente alaparte dela Epistola; queda la fábrica adeudada por ahora, enla cant de ochocientos y quatro rreales poco mas o menos" 48 . "A: 73 Enheste se fabricó la Capa dela gloriosa Virgen y martir S. Lucía, en cuya zanja seencontraron algunos sepulcros, y una lapida pequeña con caracteres roma ${ }^{o s}$ que manifiestan la antigüedad dela Igla."

Esta última anotación nos proporciona la pista sobre un hallazgo arqueológico del que hay en este libro otras citas, interesados por el tema, descubrimos que en nuestros días se desconoce el paradero de la referida lápida.

Concluida la iglesia según el gusto barroco, así llegó hasta los años sesenta del siglo veinte. En este momento buscando una mayor amplitud, precisa para el deseo de convertirla en santuario, sufrió una desafortunada transformación, que le dio su forma actual.

No hicieron grandes cambios, a lo largo del siglo XIX y primera mitad del XX, mas existen diversas partidas de dinero destinadas a sufragar los gastos ocasionados por pequeñas obras, que varían en cierta medida el aspecto que ofrecía el templo, sobre todo en la parte referente a bienes muebles.

De 1790 data la pintura del retablo e imagen de la Magdalena99: “...quinientos veinte y un $r^{s}$ importe de la pintura del retablo è imagen de $S^{\text {ta }}$ María Magdalena $y$ dos crucifijos".

No encontramos más partidas destinadas a reparos del altar mayor hasta 1802, en que figura la confección de una cortina para el camarín de la Virgen ${ }^{50}$. "Ansimismo la dá (en data) de noventa y dos $r^{s}$ coste deuna cortina cortina de seda para el Camarin de N. S ${ }^{\text {ra }}$ deel Rosario incluso fleco y echura..."

En 1807 componen la tribuna, ya que la anterior se había desplomado ${ }^{51}$. "Pri-

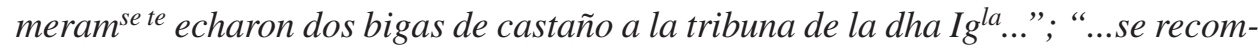
puso el piso de dha tribuna su escalera; la de el campanario; se hizo la puerta ventana...; se empino todo el maderado y fayado de sobre dha tribuna desplomada enteram $^{\text {te }}$...se armó de nuevo, y a otro ayre la ventana de la guardilla qe sirve al campanario; se hizo y asentó de nuevo una porcion de cornisa al lado deel norte y sobredha tribuna qe amenazaba rruina, e hizo paredilla y tejadillo de dha guardi-

\footnotetext{
${ }^{47}$ Libro de fábrica, f. $149 \mathrm{v}-\mathrm{vl}$

48 Libro de fábrica. f. 202

${ }^{49}$ Libro de fábrica

${ }^{50}$ Libro de fábrica, f. 204vl

51 Libro de fábrica, f. $213 \mathrm{v}-\mathrm{vl}$
} 
lla...”. En el auto de ese mismo año el canónigo de Lugo D. Vicente López y Somo$\mathrm{za}$, visitador del arziprestazgo, manda entre otras cosas 52: “...Reparen el Muro del Atrio con seguridad y altura de siete $q^{\text {tas }}$ alomenos y haciendo ensu entrada una portada decente, cubierta con Puertas enteras, cerradas con llave, sin abrirlas sino enlos días festivos y de concurrencia, dexando enel Muro un paso facil de subir pa el transito ala Iglesia enel resto de la semana".

1811, con otro párroco de la casa de Montenegro o al menos ese es su segundo apellido, pues firma Gabriel Sanjurjo Montenegro, marca el momento de reparar la imagen del santo patrón de la feligresía, el cual ha perdido alguno de sus atributos y además creen necesario volverlo a pintar, puesto que no parece probable que la efigie estuviera sin policromar hasta fecha tan tardía; sobre todo teniendo en cuenta que en la talla al ser restaurada, quedaban restos de varios repintes ${ }^{53}$. "Iten pagué al Pintor $d^{n}$ Josef Gallardo $p^{r}$ pintar la Imagen de $S^{n}$ Adriano dos cientos quarta $r^{s}$ $q^{e}$ dato"..."I It al tallista $D^{n}$ Ant ${ }^{o}$ Gruchate ocho $r^{s} p^{r}$ echura de la espada, y varilles de el sto los mismos q dato".

La orden de reconstrucción del atrio no se lleva a cabo hasta 1829, pese a la insistencia de visitadores sucesivos ${ }^{54}$. “...añol814...se rehedifique como corresponde y con la amplitud necesaria el atrio de esta iglesia poniendole supuerta con llave y candado para que se mantenga limpio y decente, dejando ademas una escalera de pasos en la pared para uso diario..." 55 "Santa Visita de Deza año de 1827... cierrese el atrio con suficiente pared y portada de canteria y puertas con llave y mas necesario para su mayor resguardo como antes de ahora está mandado..."56 "Entrego pa la pared del Atrio mil noventa $r^{s} . .$. Pago $p^{r}$ la piedra $p^{a}$ el mismo noventa y cinco $r^{s}$...Prlos carros $q^{e}$ la trajeron sesenta $r^{s}$..." Se da la circunstancia de que en tal fecha toma posesión del curato D. Felipe Pérez España, párroco con el cual volverán a emprenderse obras ${ }^{57}$. En Marzo de 1829 tomo posesion de este curato Dn. Felipe Perez España Capp ${ }^{n} q^{e}$ fue del Esc ${ }^{m o} S^{r}$ D. Hipolito Sanchez Ranjel obispo de Lugo".

Durante varios años encontramos en las cuentas de fábrica cantidades destinadas para los retablos, sin especificar en qué, ni en cuáles se emplean.

En 1839 figuran en su data dos partidas, una muy pequeña, para el arreglo de la mano de la Virgen de la Angustia y otra dedicada a la pintura de los retablos ${ }^{58}$.

\footnotetext{
52 Libro de fábrica, f. $218 \mathrm{v}-\mathrm{vl}$

53 Libro de fábrica, f. $225 \mathrm{v}$

${ }^{54}$ Libro de fábrica, f. $228 \mathrm{v}$

55 Libro de fábrica, f. $245 \mathrm{vl}$

56 Libro de fábrica, f. $249 \mathrm{v}$

57 Libro de fábrica, f. 204

${ }^{58}$ Libro de fábrica, f. $254 \mathrm{v}$
} 
“...componer una mano a la Virgen de las Angustias doce reales" “...Para pintar los retablos entregó dos cientos diez reales" $\mathrm{Al}$ año siguiente ${ }^{59}$ "Para los retablos entregó tres cientos treinta y cuatro." Hay otra en mayo siguiente ${ }^{60}$ "Pintura de los retablos en 1840".

Tras todas estas partidas un poco confusas y repetitivas encontramos que en 1846 hicieron el cementerio ${ }^{61}$ : "En 1846 se hicieron ...los zementerios de las dos Yglesias..."El camposanto es ampliado en 186262: "En un pedazo de terreno que le compró a José Neyra $p^{a}$ ensanchar el Atrio $p^{r}$ la parte del mediodía, cuatrocientos $r^{s}$." y aun en 1865 invierten dinero en él

Continúan las cuentas de la fábrica en otros dos libros, pero no hay apenas obras de interés.

Así vale la pena citar que las imágenes del retablo mayor reciben una mano de pintura en el 80, todas ellas, a excepción de la Virgen del Rosario ${ }^{63}$. "Pintar S. Pablo, S. Pedro y S. Adriano (Imagines) que estan en el Altar maior trescientos reales, según recibo de D. Pablo Ojea."

1882 y 1884 sirven de marco para hacer el frontis de la iglesia basándose en el plano encargado al arquitecto D. Alejandro Sesmero. Para la obra es necesario labrar sesenta y nueve piedras de granito, tarea que dirigirá el Maestro D. José de Carballal. Las obras se adjudicaron en pública subasta al mejor postor que fue D. Manuel Cuñarro, vecino de San Juan de Botos.

La puerta principal fue donada por el párroco y los feligreses, encargándose de su pintura, D. Andrés Ramos, un ex canónigo de Buenos Aires.

En 1894 se efectuaron algunos cambios, como techar y poner cielo raso a la capilla de Santa Lucía además de retocar su retablo y el de la Angustia; pintándose también los arcos de las bóvedas.

El campanario deciden rematarlo con una cruz que colocan en 1897.

Pasada la primera década del siglo XX es necesario encargar un pórtico conmulgatorio y dos púlpitos, aunque ya se tenían noticias de la existencia de al menos un púlpito, pues en 1895 habían mandado hacer unas rejas para él.

Las cuentas de 1913 incluyen la adquisición de dos nuevas imágenes que aun permanecen hoy en el templo San José y un Sagrado Corazón de Jesús ambas de cartón madera.

\footnotetext{
${ }^{59}$ Libro de fábrica, f. $256 \mathrm{v}$

${ }^{60}$ Libro no. I (1581-1820), f. 204

${ }^{61}$ Libro de fábrica, f. 204

62 Libro de fábrica, f. $257 \mathrm{v}$

${ }^{63}$ Libro de fábrica, f. s/f
} 
Al comenzar los años veinte se precisa una nueva tribuna, sustituyéndose la techumbre en 1926, fecha en la que se hace imprescindible asegurar un arco del presbiterio reemplazando su clave por una nueva.

El patrimonio mueble se enriquece en 1922 con un viacrucis.

Iniciamos la tercera década con una reparación en el altar de Santa Lucía y la limpieza de los elementos de cantería de la iglesia, probablemente sea este el momento en el que se perdieron gran parte de las pinturas que la decoraban.

En el 43 se adquiere la Inmaculada a indicación de D. Antonio Riádigos que sufraga su coste.

La relación de gastos de 1946 contiene una partida dedicada a la compra de un nuevo viacrucis, esto llama nuestra atención dado que no hacía muchos años que se había adquirido uno de estos conjuntos y no debía de presentar tan mal estado que obligase a cambiarlo, si bien esta sustitución pudo hacerse en ánimo de mejorarlo.

1948 es la fecha de una nueva restauración de las imágenes del Sagrado Corazón, Santa Lucía, San Adrián, la Virgen del Rosario y Santa María Magdalena. Con ese fin, son trasladadas a Santiago a un taller que no especifican, aunque en el reverso del folio, al final de los asientos de gastos añade 64 : "Por involuntario olvido, no se consignó en el asiento $n^{\circ} 7$ la cantidad de setecientas pesetas que importó mas esta partida por cuanto la Imagen Virgen del Rosario se hizo nueva a excepción de la cabeza que se aprovechó de la antigua". Gracias a esta indicación sabemos ya que fue de aquella imagen del siglo XVIII de la Virgen del Rosario que hoy no encontramos, aunque por lo que se refiere de ella en el Libro de la Cofradía de ese nombre en el apartado titulado "Estatutos particulares de la Coffradia de Numero del $S^{\text {mo }}$ Rosario erigida canonicamente en la Yglesia de San Adriano de Moneijas", en su artículo 11 nos enteramos de que era una figura de vestir, pues allí dice: "Es cargo delas dos Hermanas Camareras dela Virgen, bestir la Ymagen, cuidar desus ropas y halajas, y asi mismo cuidar ó procurar el aseo ó limpieza del Altar dela Cofradia."

También en el art. 14 de los "Estatutos" insiste: "Se nombrarán dos Hermanas de virtud que vistan la Ymagen de la Virgen y cuiden de sus ropas y asimismo del aseo y limpieza del altar de la Cofradia".

De tal modo pensamos que la imagen primitiva de Ntra. Sra. del Rosario fue, como tantas otras del Barroco, una estructura sencilla de madera para vestir con cabeza y manos de talla y ojos de cristal, la cual por el paso del tiempo y dada la precariedad de su armazón, unos simples maderos, debió deteriorarse y por tanto fue preciso repararla, decidiendo sustituirla; aunque por la devoción que inspiran

${ }^{64}$ Libro de fábrica, f. $91 \mathrm{v}$ 
las efigies y lo impopulares que son los cambios de ellas, pensaron que sería oportuno conservar la cabeza, para suavizar tan drástica solución.

Nuevas tareas de restauración y pintura se abordan en 1949 dirigidas hacia los tres retablos de la iglesia.

También se faya de nuevo la capilla de las Angustias y pintan los techos de las capillas, así como se retocan púlpitos y verja del presbiterio, pintan la imagen de San Antonio y reparan la de la Magdalena.

En 1958 se hará la instalación eléctrica de la iglesia.

Tras estas mejoras que han ido realizando durante la primera mitad del siglo, llegará la hora de la que tal vez sea la obra más importante que se acomete en el templo, desde la construcción de las capillas laterales. Se trata de la creación de la Capilla-Santuario que llevará a cabo el maestro de obras D. Vidal Payo Fernández en 1960, siendo párroco D. Andrés Cajide.

La Capilla-Santuario dedicada a la TOC, cuya patrona la Virgen del Carmen preside su retablo, construido, dorado y decorado por D. Avelino Martínez Gulín de Orense entre 1962-63.

Situada a la izquierda de la nave, ocupa y hace desaparecer la capilla de la Angustia, para prolongarse hasta los pies del templo, constituyendo una autentica segunda nave; que se separa del cuerpo de la iglesia mediante tres arcos de diferente luz, apoyados sobre pilares de hormigón.

Hacia el exterior, un frontis, de características semejantes al del que cierra el templo, coronado en lo alto por una enorme Virgen petrea de dos metros y medio, limita la capilla por el oeste, disponiéndose sobre la puerta el escudo carmelitano y en el frontón una placa con las iniciales TOC (Tercera Orden Carmelitana).

Entre los años 1965-66, encontramos en la fábrica partidas destinadas al taller de carpintería del señor Trabazo de Lalín al que le encargan la ornamentación de castaño dice de Moneixas y creemos que se refiere al revestimiento ligneo de la Capilla-Santuario.

Otras novedades se introducen en estos años finales de los sesenta en la iglesia, con un afán más funcional, es el caso de la instalación de los altavoces y la compra de un reloj-carrillón en la Casa Marín de Barcelona.

Llegados los setenta, es necesario pintar el altar y la Virgen del Carmen del Santuario, tarea que se confía al taller compostelano de D. Angel Rodríguez, en el cual también se encargarán de realizar las vidrieras pintadas que se incorporan a la última capilla.

En 1974 llega el párroco actual, D. Luis López Barredo, que ha de ocuparse del arreglo de la casa rectoral y por fortuna no hará grandes intervenciones en la iglesia, a excepción de esta última y cuidada restauración. 
El inmueble tras haberle sido añadido el Santuario ha visto desfigurado el espacio original del templo románico, el cual con las obras llevadas a cabo durante el Barroco aparecía transformado constituyendo un modelo de evolución históricoartística muy repetido en Galicia.

Sinceramente creemos que pese a que la nueva capilla debió parecerle a sus fundadores un elemento que enriquecía la modesta iglesia rural de Moneixas, estos tal vez por falta de sensibilidad artística y de los conocimientos suficientes, no fueron conscientes del atentado contra el patrimonio que suponía semejante anexo.

Estos últimos años han intentado mantener el templo en el mejor estado posible y poner los medios adecuados para recuperar los elementos que dotados de cierto valor histórico-artístico lo habían perdido por el paso inexorable del tiempo y por las manos inexpertas a las que se había confiado su mantenimiento.

\section{PINTURA MURAL}

La pintura está situada en el muro de la Epístola de la capilla mayor. Enmarcada en un recuadro con una greca decorativa, en ella se distinguen tres personajes que componen la flagelación, tratada de una forma muy curiosa

En los libros de la iglesia conservados no se menciona en ningún momento, ni tampoco hemos encontrado alusión alguna hacia ella en la bibliografía consultada, por lo que podemos atrevernos a decir que estamos ante un ejemplar inédito de pintura mural, lo cual tampoco es nada extraño pues en los últimos años están apareciendo muros pintados en buen número de iglesias, en las que tales obras eran desconocidas por encontrarse recubiertas por cales o incluso por retablos que las ocultaban, caso que como ya indicamos, también se da en Moneixas tras el retablo mayor. Sin embargo llama la atención y sin duda es singular, la temática representada, sobre todo por lo original de la iconografía elegida.

Respecto a su datación, parece por su aspecto poder situarse aproximadamente hacia el final del siglo $\mathrm{XV}$, fecha en la que se realizan otras pinturas de semejante factura.

Para apoyar la tesis de su cronología, podemos fijarnos en la indumentaria de los personajes, lo cual nos conduce a pensar en la similitud de las distintas piezas de la vestimenta con modelos cuya datación conocemos que se corresponden con la segunda mitad del XV. De esta forma podemos tomar como referencia, a modo de ejemplo, la ilustración de un códice de la Biblioteca del Palacio Real conocido bajo el título de "Genealogía de los reyes por D. Alonso de Cartagena" que D. Elías Tormo examina y comenta en su obra "Las viejas series icónicas de los reyes 
de España", fechándolo hacia 1460. Allí alude a la influencia, que ya había apuntado E. Mâle de "la transformación del arte del siglo XV por los "Misterios", o sea que en las representaciones sagradas pictóricas influyó mucho la caprichosa indumentaria de los que representaban en los templos los dramas litúrgicos tan populares entonces". Esto puede apreciarse en detalles como los chapines, de larga y exagerada punta. En nuestro caso los chapines que calzan los sayones pertenecen a este tipo de zapatos. Como también coinciden otras prendas con las usadas por varios personajes de aquella genealogía, en donde se aclara "siendo en puridad los tipos, los trajes civiles... cosa del tiempo del dibujante". Entre tales ropajes coinciden con los dibujos del códice, calzas ceñidas, el jubón de rica tela, en esta ocasión brocado, ajustado a la cintura con cinturón y mangas "menos prietas" que se diferencia en nuestro caso en que no es este jubón de falda corta como allí describen, al que corresponde al traje de paje o doncel.

Respecto a los tocados, que en el libro son de lo más estrambótico, nuestra representación opta por unos gorros frigios de bastante fantasía, sobre todo teniendo en cuenta que los que los portan son dos simples esbirros, mientras que los personajes que ilustran el códice palaciego son siempre miembros de la realeza y por tanto es lógico que se les dote de atuendos más exuberantes.

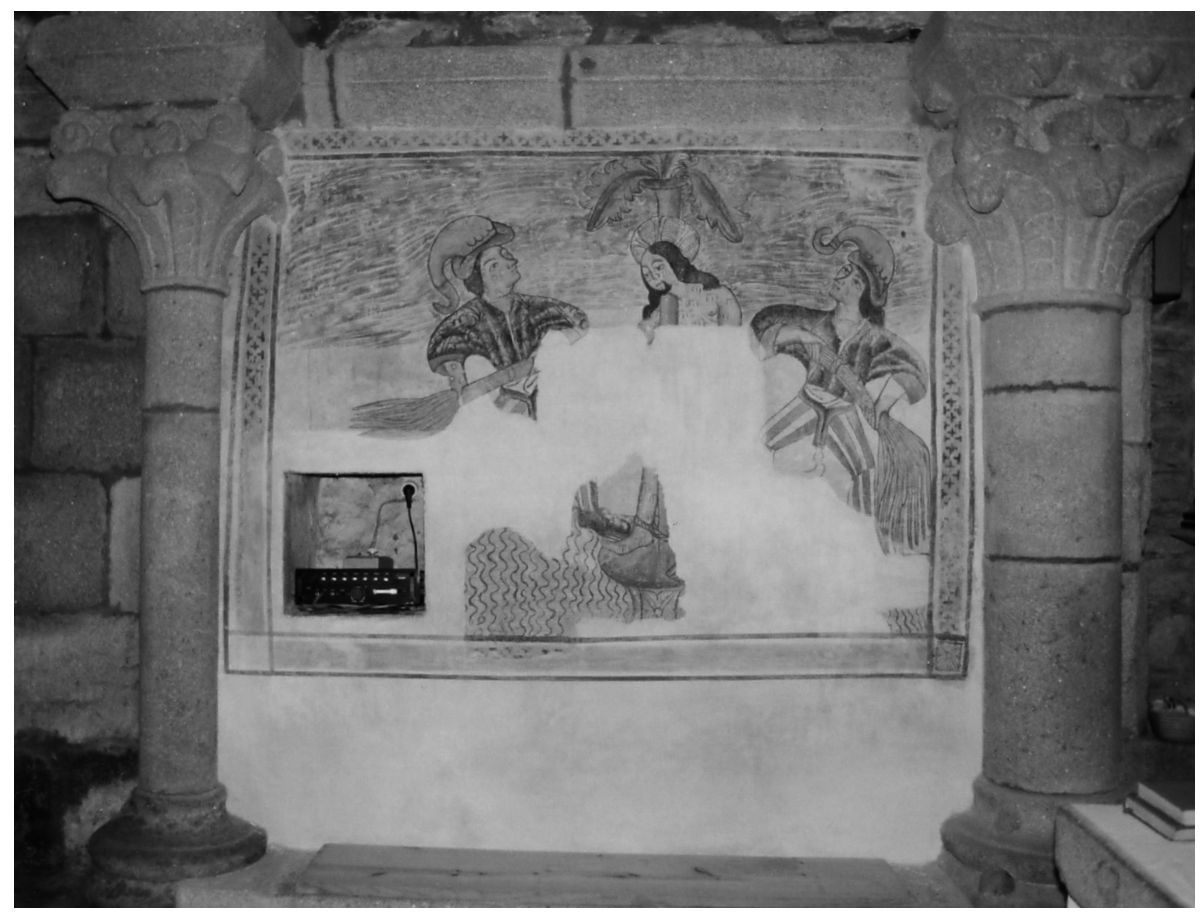




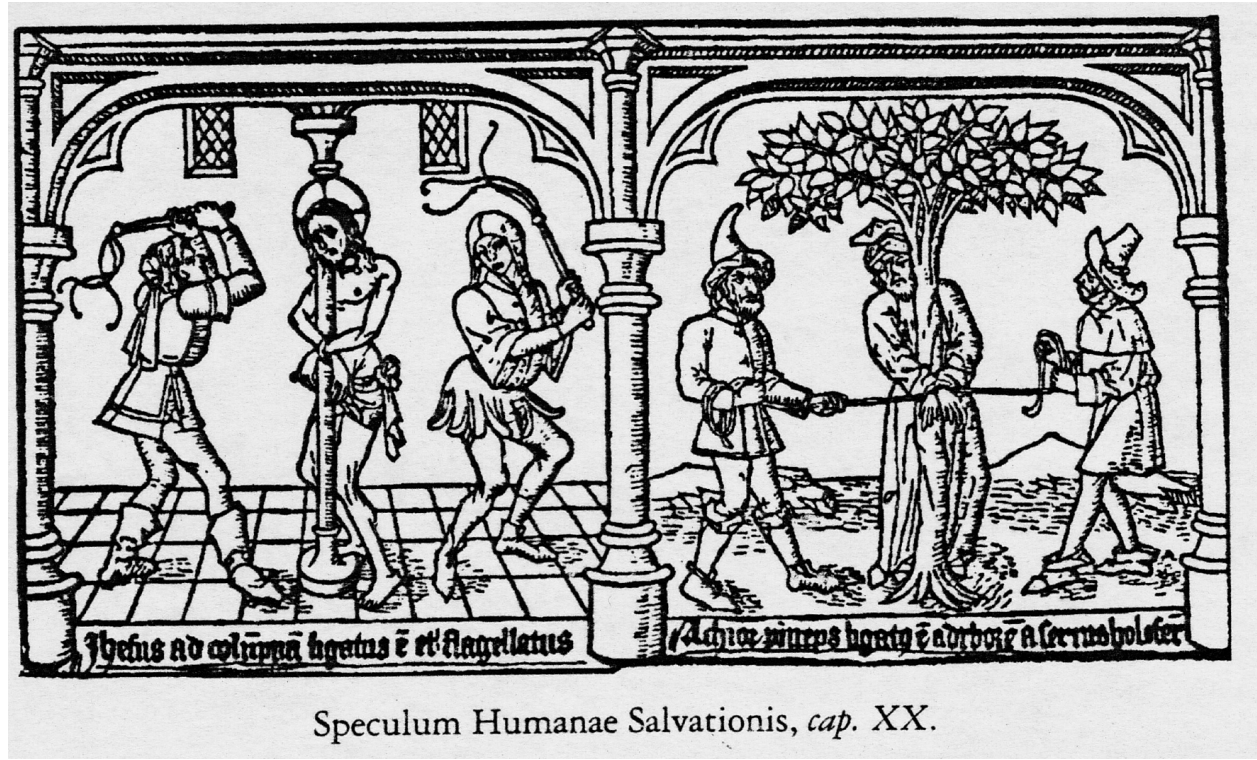

Por otro lado también es curioso que la greca que enmarca la escena sea muy similar, e incluso podríamos decir igual, a la que bordea las pinturas murales del ábside de la iglesia parroquial de Marzá (Palas de Rey), no muy lejana geográficamente de Moneixas y catalogadas en el Inventario del Patrimonio Artístico de España correspondiente a Lugo y su provincia como del siglo XV, avanzando la datación hasta los primeros años del XVI (¿1503?) según el estudio mucho mas reciente referido en la bibliografía, del profesor García Iglesias.

\section{ICONOGRAFIA}

El tema es la flagelación, pero la representación del mismo es muy notoria, rara y excepcional, pues el flagelado no hay duda que es Cristo, de ahí que lleve el nimbo crucífero con las potencias. Aparece de pie desnudo, no podemos apreciar la forma del paño de pudor, ya que una laguna en la pintura nos impide verlo. Numerosas gotas de sangre salpican todo su cuerpo. Está atado y aquí viene lo más original, a un largo cilindro con su base, sobre la que reposan los pies del Señor y de cuya parte superior salen unas hojas de palma, asimilando lo que debía de ser una columna con una palmera. A los lados dos sayones, ataviados, como hemos visto a la moda del siglo $\mathrm{XV}$, portando entre sus manos grandes haces de varas con los que azotan a 
Jesús. Muestra uno de ellos laceraciones, que podríamos identificar con pústulas que invaden todas las zonas en que su cuerpo está desnudo, cara, brazos, manos.

¿Qué es esto y por qué se representa así? La cuestión no es fácil, y pese a haberle dedicado muchas horas, no hemos sido capaces de encontrar este modelo iconográfico en ningún otro lugar, si bien vamos a plantear una hipótesis que creemos tiene sentido y podría aportar luz sobre el caso.

Para ello ha de recurrirse al arte prefigurativo medieval que presenta episodios de la vida de Cristo recogidos en el Nuevo Testamento denominados "typos" a través de "antitypos" o escenas del Antiguo, método tipológico de la teología aplicado a la iconografía cristiana basado en el paralelismo entre ambos testamentos que San Agustín, siguiendo a San Lucas que dice (Lc. 18,31): "Todo lo que ha sido escrito por los profetas se va a cumplir para el Hijo del Hombre", define muy bien en "La ciudad de Dios"(XVI,26): "el Antiguo Testamento es el Nuevo cubierto con un velo, y el Nuevo es el Antiguo desvelado". La iconografía recoge estas ideas proponiendo figuraciones en las que se confirme el paralelismo entre ambos Testamentos. Estos conceptos vienen de antiguo resurgiendo la interpretación tipológica de la Biblia con la escolástica en el siglo XII, aunque hemos de esperar a mediados del XIII para que se materialicen graficamente en la "Biblia Pauperum", manual anónimo que aunque contaba con un texto, lo fundamental en él eran las imágenes que apoyaban aquél y que tuvo una edición xilográfica un siglo después, siendo muy usado por los monjes predicadores a los que resultaba imposible acceder a una copia de la Biblia completa. Poco después, a principios del XIV se compuso el "Speculum Humanae Salvationis", nuevo manual destinado al mismo uso que el anterior y también ilustrado, aunque en este caso se dedique a la interpretación del Nuevo Testamento a través de las prefiguraciones del Antiguo. Pronto alcanzará gran difusión sobre todo porque ofrecía comentarios breves ${ }^{65}$, "enriquecidos por interpretaciones de los Padres y Doctores de la Iglesia y ampliado por textos de los Apócrifos, de la Historia Scholastica de Pedro Comestor, de la Leyenda Aurea de Jacobo de la Vorágine y de las Antiguedades Judaicas de Flavio Josefo."

$\mathrm{Y}$ es aquí, en este manual, en donde en el capítulo XX nos encontramos con que dicho capítulo está dedicado a la Flagelación (Mateo 27,26; Lucas no lo recoge; Juan 19,1 y Marcos 15,15) entre sus prefiguraciones, que son tres, aparecen:

A) Lamec golpeado por sus esposas Ada y Sillá (Génesis 4, 19-24)

B) Job golpeado por su mujer y un demonio (Libro de Job 2, 7-10)

C) El rey Aquior atado a un árbol y golpeado por los esbirros de Holofernes por haberle dicho la verdad (Judit 6, 7-13)

${ }^{65}$ Mensaje simbólico del arte medieval, p. 391 
Es Precisamente esta escena "C", que es la que forma pareja con la flagelación en el Speculum Humanae Salvationis.

El vínculo entre ambas escenas y su fusión en una sola imagen es lo que tal vez quiera representarse en el muro de Moneixas. Esto tiene su lógica, si tenemos en cuenta que durante el gótico las fuentes literarias son las que determinan la temática, adoptando esta un fin narrativo que utiliza un lenguaje convencional por el que adquieren sentido los motivos elegidos.

Sin embargo, cabe preguntarse: ¿cómo llegó esto aquí?, pues en España apenas debió de haber ejemplares del Speculum, de hecho en nuestros días tan sólo se conocen, dos manuscritos del siglo XV que posee la Biblioteca Nacional y hay noticias de un tercero guardado en la catedral de Toledo hasta la Guerra Civil, momento en que se perdió. Además, pese a que fue una obra que del latín se tradujo a muchos idiomas, no consta que el español fuera uno de ellos y hasta la fecha no ha aparecido ninguno en esta lengua.

Ante semejante situación no nos parece descabellado plantearnos si tal vez el artista pudiera ser extranjero o al menos hubiese estado fuera de España algún tiempo, durante el cual habría tenido la ocasión de conocer algún ejemplar del códice.

Otra posibilidad sería, que quien encargase la obra fuese el que había tenido acceso al Speculum fuera de nuestras fronteras y esto parece más factible, dado que en el siglo XV no suelen ser los artistas los que escogen los temas ni la manera de representarlos, sino los que encargan sus trabajos, generalmente eclesiásticos, asesorados por gentes de letras.

Todavía y tomando como referencia una sugerencia que apunta Louis Réau en su "Iconografía del arte cristiano", se nos ocurre otra posibilidad. Dice Réau: "En el siglo XV, este tema (se refiere a las prefiguraciones de la Flagelación) fue representado con frecuencia como frontispicio, en las sedes (mariengole) de las cofradías de flagelantes."

En España las cofradías de flagelantes son un fenómeno tardío y no del XV, con anterioridad a esa fecha los disciplinantes surgen en Italia en el siglo XIII y se extienden sobre todo hacia el norte de Europa, alcanzando gran auge tras las epidemias de pestes que asolan aquellas tierras. Ello nos conduce de nuevo a pensar que estamos ante un artista o más bien un promotor extranjero o que han conocido otros lugares allende los Pirineos, en donde hayan podido ver alguna de estas sedes y que una vez aquí, han querido hacer una representación similar a lo que hayan visto. Incluso cabe la posibilidad, de que esas personas vinieran hasta este extremo de la Península, huyendo de alguna de las persecuciones de las que con frecuencia eran objeto los flagelantes.

Una vez expuestas estas hipótesis vamos a intentar pormenorizar un poco más en detalles del mural. 


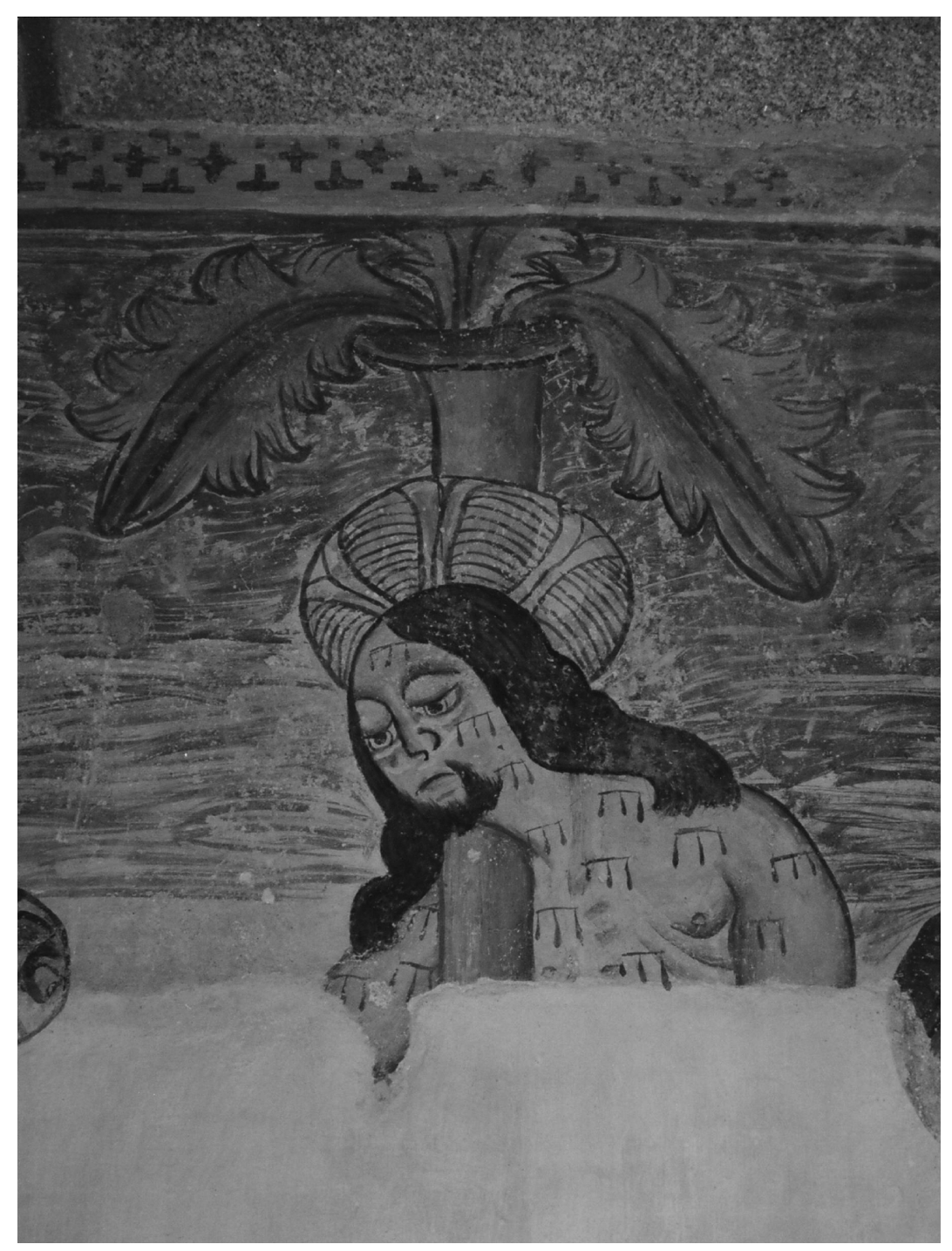

La figura de Cristo en pie resulta muy curiosa, dado que no muestra, como suele ser habitual en sus representaciones, barba corrida y bigote, aquí el bigote no existe y la barba se ha convertido en una suerte de perilla.

El pelo lo lleva largo, cayéndole sobre los desnudos hombros.

En cuanto al rostro tiene una expresión resignada, aunque doliente, resaltándole las bolsas bajo los ojos y las salpicaduras de la sangre manan por todo su cuerpo, pese a ser pintadas con bastante ingenuidad y repetición en la forma. 
Del cuerpo sólo se aprecia la parte superior del tórax desnudo, con uno de cuyos brazos rodea la columna por detrás, para cruzar ambas manos delante del fuste en donde se atarán. Aunque esto no lo podemos ver aquí por la falta del mortero que servía de soporte a los pigmentos. En la zona inferior, vemos una pierna atada a la altura del tobillo, mediante una soga, a la parte donde comienza la base del elemento híbrido arquitectónico vegetal y los dos pies, aunque del derecho apenas se ve nada más que la punta de los dedos.

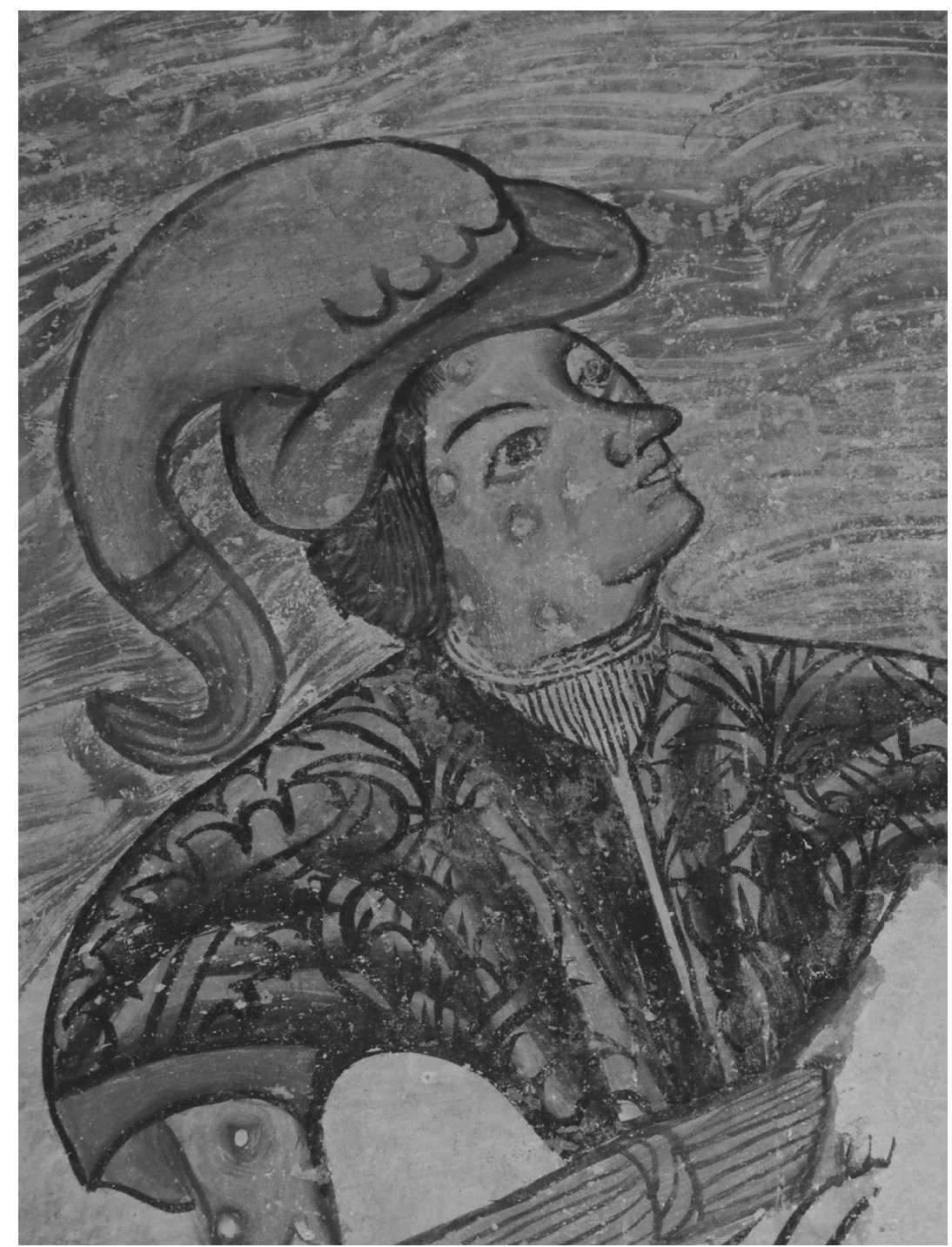


Los verdugos con gorros de tipo frigio, rematados en punta, recuerdan en cierta manera al que usa uno de los esbirros de Holofernes atando al rey Aquior en la imagen del Speculum del siglo XV manejado ${ }^{66}$.

Tienen las narices pronunciadas, sobre todo si las comparamos con la de Jesús, es posible que denoten cierto aire caricaturesco propio de tales representaciones, que ayuda a recalcar su naturaleza vil y carácter brutal; así como su condición judía, ya que a los judíos la iconografía gótica los representa con sombreros puntiagudos y narices prominentes, en un intento de recrear el feo aspecto que presentarían aquellos que crucificaron a Cristo, sin recordar que también Jesús pertenecía a ese pueblo y por tanto es lógico que tuviese sus mismas características raciales.

En la misma línea están las pústulas a las que en párrafos atrás nos hemos referido; y también los dientes, que enseñan para acentuar su ferocidad.

Los ropajes ricos y a la moda de su tiempo (tiempo en que fue hecha la pintura) son signo del poder del gran señor al que sirven, léase Holofernes o Pilatos. Sin olvidarnos de lo apuntado anteriormente relativo a la escenificación teatral.

Respecto al número de sayones es frecuente que aparezcan tres y que al menos uno de ellos porte el látigo que da nombre a la escena, flagelo, pero este no es el caso. Aquí se pintan dos y ambos portan el mismo tipo de haz de varas, sin que estas rotas tras los golpes hayan caído al suelo, como muestran algunas conocidas representaciones.

Precisamente el suelo nos sorprende por su esquemático dibujo de ondas, que no acertamos a explicar, porque es la forma más habitual de simbolizar el agua, pero esto aquí no tiene sentido.

El fondo se logra a base de manchas de trazo alargado, sin gran esmero.

Y por último el elemento más controvertido, la columna. Pese a la base que no se asemeja a la de las columnas habitualmente representadas, en ésta y teniendo en cuenta la torpeza en la habilidad dibujística del artista, podemos ver cierta similitud con la dibujada en el Speculum, con esa forma un tanto acampanada y una especie de plinto debajo, que en la pared se estrecha de tal modo, que nos hace dudar de sí eso es en verdad un plinto, pues es de dimensiones más reducidas que el toro y además va decorado con un motivo floral semejante a los de las esquinas de la greca. El fuste cilíndrico parece abrirse en un borde saliente que rodea la boca por donde asoman las hojas de palma y en este punto sí que se aprecia una gran diferencia; el árbol de la escena de Aquior del Speculum, es una frondosa especie de pequeñas hojas, mientras aquí el árbol es una palmera. Desde

${ }^{66}$ Speculum Humanae Salvationis. Ed. anotada por Adrian Wilson y Joyce Lancaster Wilson. 
luego no hay duda de que esta especie arbórea es mucho más característica de la tierra donde vivió Jesucristo que cualquier otra, pero salvo en las iconografías del Día de Ramos, en donde Jesús es aclamado por una multitud que agita palmas o en la de la Huida a Egipto, en la que suele haber alguna palmera que cobije con su sombra y proporcione sus frutos a la Virgen con el Niño, no es muy habitual que las palmeras sean elegidas como árboles para realizar una composición pictórica.

Si bien, siguiendo el estudio de Gombrich acerca del capitel, que recoge a su vez las teorías de Riegl en la introducción de su obra "Stilfragen", podemos estar frente a uno de esos capiteles evolucionados y metamorfoseado precisamente en una planta autóctona de la tierra de Cristo.

Riegl dice "que la historia de la ornamentación vegetal clásica podía continuar a través de la Edad Media hasta el Renacimiento" y desarrolla una interesante teoría sobre la evolución del motivo ornamental de la palmeta, la cual deriva en la hoja de acanto siguiendo una hipótesis de continuidad que hace reaparecer este motivo una y otra vez, pasando de formar parte del capitel corintio a alcanzar una gran exhuberancia en Bizancio, en los capiteles románicos y en el mundo gótico donde el follaje se metamorfosea en plantas autóctonas

Aceptando dichas teorías, Gombrich plantea la duda de si los artesanos góticos representaron sus impresionantes capiteles vegetales inspirados a partir de la observación de plantas vivientes existentes en la naturaleza o si continuaron el esquema tradicional de la hoja de acanto, como elemento primordial del capitel vegetal clásico, evolucionada hacia formas de la flora autóctona; sea cual sea la solución adoptada, ambas son válidas en nuestro caso y sirven para considerar las hojas de palmera sobre el tronco-fuste, como el capitel de la columna del Pretorio.

Además la palmera simboliza la victoria, el triunfo, la rectitud. Así como en la mano de los mártires es símbolo de la rectitud de su fe, de la victoria sobre el espíritu del mal y del triunfo de la vida y de la recompensa eterna; aquí coronando uno de los instrumentos del suplicio, sugerimos que puede interpretarse como el triunfo sobre la muerte a través del sufrimiento de la Pasión del cual resurge (brota de la columna), significando la resurrección que será la fuente de la nueva vida.

De lo que estamos seguros es de que nos encontramos ante una pintura cuando menos singular y como tal debe ser reconocida por los amantes del arte. 


\section{BIBLIOGRAFÍA}

A.A. V.V. Inventario artístico de Lugo y su provincia. t. IV. Ministerio de Cultura. Madrid, 1980.

ÁlVAREZ LIMESES, Gerardo. Pontevedra, t.II. En Geografía General del Reino de Galicia, v. XIII. Ed. Gallegas. La Coruña, 1980.

BANGO TORVISO, Isidro. Arquitectura románica en Pontevedra. Fundación Pedro Barrié de la Maza. La Coruña, 1979.

BARALLAT Y FALGUERA, Celestino. Principios de botánica funeraria. Ed. Alta Fulla. Barcelona, 1984.

BAUDRILLART, A., DE MEYER, A. y VAN CAUWENBERH, Et. Dictionnaire D'histoire et de géographie ecclésiastiques. t. IV. Paris, 1931. Librairie Letouzey et Ané.

CARMONA MUELA, Juan. Iconografía clásica. Guía básica para estudiantes. Istmo. Madrid, 2000.

CIRLOT, Juan Eduardo. Diccionario de símbolos. Ed. Labor. Barcelona, 1991.

CHARBONNEAU-LASSAY, Louis. El bestiario de Cristo. José J. Olañeta, Ed. Barcelona, 1997.

DOMÍNGUEZ RODRÍGUEZ, Ana. La miniatura en la corte de Alfonso X. En Cuadernos de Arte Español, $n^{o} .35$. Grupo 16. Madrid, 1992.

FONTANA, David. El lenguaje secreto de los símbolos. Una clave visual para los símbolos y sus significados. Círculo de lectores. Barcelona, 1993.

GARCÍA CONDE, Antonio y LÓPEZ VALCÁRCEL, Amador. Episcopologio lucense. Liceo Franciscano. Burgos, 1989.

GARCÍA IGLESIAS, J. M. El barroco. En Galicia Arte. v. XIV. Hércules. A Coruña,1993.

GARCÍA IGLESIAS, X. M. Pinturas murais de Galicia. Inventario do patrimonio histórico galego. Xunta de Galicia. Santiago, 1989.

GOMBRICH ESENCIAL. La fuerza del hábito. Ed. de Richard Woodfield. Debate. Madrid, 1997.

IMPELLUSO, Lucia. La naturaleza y sus símbolos.Plantas, flores y animales. Electa. Barcelona, 2005.

LÓPEZ TERRADA, M Mosé. Las plantas ornamentales. En Jardín y naturaleza en el reinado de Felipe II. Sociedad Estatal para la Conmemoración de los Centenarios de Felipe II y Carlos V. Madrid, 1998.

MADOZ, Pascual. Diccionario geográfico, estadístico, histórico de España y sus posesiones de ultramar. t. IV. Libros Galicia. Madrid, 1986.

MANSO PORTO, Carmen. A pintura e a miniatura. En Galicia Arte. v. XI. Hércules. A Coruña, 1993.

MARTÍN GONZÁLEZ, J.J. Escultura barroca en España.1600 - 1770. Cátedra. Madrid, 1983.

REAU, Louis. Iconografía del arte cristiano. Iconografía de la Biblia. Nuevo Testamento. Ed. Serbal. Barcelona, 1996.

REAU, Louis. Iconografía del arte cristiano. Iconografía de los santos. Ed. Serbal. Barcelona.1997, 98. 
SÁ BRAVO, Hipólito de. Rutas del románico en la provincia de Pontevedra. Ed. Caja Rural. Vigo, 1978.

SAGRADA BIBLIA. The Catholic Press, Inc. Chicago, 1966.

SEBASTIÁn, Santiago. Mensaje simbólico del arte medieval. Arquitectura, liturgia e iconografía. Encuentro Ed. Madrid, 1996

SICART GIMÉNEZ, Angel. Aspectos iconográficos de las pinturas de Vilar de Donas. En Jubilatio. T.II. Universidad de Santiago de Compostela,1987.

SICART GIMÉNEZ, Angel. Pintura medieval: la miniatura. Arte Galega Sanchez Cantón. Santiago de Compostela, 1981.

TORMO, Elías. Las viejas series icónicas de los Reyes de España. Junta de Iconografía Nacional. Madrid, 1917.

TRAPERO PARDO, J. Pintura mural. En Cuadernos de Arte Galego, 10. Vigo, 1965.

VALIÑA SAMPEDRO, Elías. Catálogo de los archivos parroquiales de la diócesis de Lugo. Servicio de publicaciones de la Diputación Provincial. Lugo, 1991.

VILA JATO, Ma Dolores. Promotores, clientes y talleres en la Galicia barroca. En Actas do I Congreso Internacional do Barroco. v. II. Porto, 1991.

VORAGINE, Santiago, de la. La Leyenda Dorada. Alianza Ed. Madrid, 1990.

\section{DOCUMENTACIÓN}

- Libros de Fábrica: (En la casa rectoral de Moneixas)

- Memorial delarr ${ }^{\text {ta }}$. que actualmente tiene la fabrica dela Igla deS Adriande Moneijas, y delas misas que enella sedeben celebrar.1672-1880.

- Libro de fabrica de San Adrian de Moneijas, que comienza en el año de 1881. Siendo cura D. José María Gil Yglesias de Santiago de Sá en Dozon. (llega hasta 1992)

- Libro de fabrica de la parroquia de Santiago de Catasós, que principia en el año de 1881 siendo cura D. José María Gil Yglesias natural de Santiago de Sá en Dozon.(llega hasta 1895)

- Libro de los papeles pertenecientes a las Yglesias y Yglesarios de las feligresias de Sant ${ }^{\circ}$ de Catasós y S. Adrian de Moneijas, siendo cura $\mathrm{D}^{\mathrm{n}}$ Pablo de Verea y Aguiar año de 1765.(Se encuentra en el Archivo Central Diocesano Parroquial del Obispado de Lugo, en donde lo titulan: Legajos sobre apeos, foros, pleitos, etc. Libro I Años1581-1820.)

- Noticias individual de lo trabaxado y prefectado en las Iglas de Moneixas, y Catasós, sus casas y Diestros desde el año de 1737 que entró a ser cura aunqe el mas indigno D. Pablo de Berea Aguiar natural de la fra de S. Martin de Calvos de sobre camino, casa de junto a su Ig ${ }^{\text {la. }}$ Jurisd ${ }^{\text {on }}$ de Arzua Arzobp $^{\text {do }}$ de Santio por titulo de D. Pedro Joseph Monten ${ }^{\circ}$ Mosqueras y Oxea Dueño de la Casa de D. Frean y sus cotos. (En el Archivo Diocesano de Lugo)

- Libro de Fundación. Capellania de la VOT de Nuestra Señora la Virgen del Carmen erigida canonicamente en el mes de Mayo de 1946 en Moneijas por el R ${ }^{\text {vdo }}$ Dn Andrés Cajide Varela, Párroco y Director-Fundador. (En la parroquia) 
- Estatutos particulares de la Coffradia de Numero del S ${ }^{\mathrm{mo}}$ Rosario erigida canonicamente en la Yglesia de San Adriano de Moneijas. (En la parroquia)

- Beneficio de Moneijas 1580. (Archivo Histórico Nacional)

- Beneficio de Catasós y Moneijas 1616. (AHN)

- Beneficio de Catasós, Moneijas y San Juan de Lajeas 1670-1713. (AHN)

- Beneficio de Catasós y Moneijas 1676. (AHN) 